Bond University

Research Repository

\title{
Perceived wellness associated with practice and competition in Ncaa Division I football players
}

\author{
Wellman, Aaron D; Coad, Sam C; Flynn, Patrick J; Siam, Ty K; McLellan, Christopher P \\ Published in: \\ Journal of Strength and Conditioning Research
}

DOI:

10.1519/JSC.0000000000002169

Link to output in Bond University research repository.

Recommended citation(APA):

Wellman, A. D., Coad, S. C., Flynn, P. J., Siam, T. K., \& McLellan, C. P. (2019). Perceived wellness associated with practice and competition in Ncaa Division I football players. Journal of Strength and Conditioning Research, 33(1), 112-124. https://doi.org/10.1519/JSC.0000000000002169

\section{General rights}

Copyright and moral rights for the publications made accessible in the public portal are retained by the authors and/or other copyright owners and it is a condition of accessing publications that users recognise and abide by the legal requirements associated with these rights.

For more information, or if you believe that this document breaches copyright, please contact the Bond University research repository coordinator. 


\title{
PERCEIVED WELLNESS ASSOCIATED WITH PRACTICE AND COMPETITION IN NCAA DIVISION I FOOTBALL PLAYERS
}

\author{
Aaron D. Wellman, Sam C. Coad, Patrick J. Flynn, Ty K. Siam, Christopher P. McLellan
}

Bond University

Aaron Wellman, MS

Bond University

Queensland, AUSTRALIA

\section{ABSTRACT}

The present study assessed the influence of movement demands resulting from weekly practice sessions and games, on perceived wellness measurements taken post-game (Sunday) and 48 hours pre-game (Thursday) throughout the in-season period in National Collegiate Athletic Association (NCAA) division I football players. Thirty players were monitored using GPS receivers (Catapult Innovations OptimEye S5, Melbourne, Australia) during 12 games and 24 in-season practices. Movement variables included low-intensity distance, medium-intensity distance, high-intensity distance, sprint distance, total distance, player load, and acceleration and deceleration 
distance. Perceived wellness, including fatigue, soreness, sleep quality and quantity, stress, and mood, was examined using a questionnaire on a 1-5 Likert scale. Multilevel mixed linear regressions determined the differential effects of movement metrics on perceived wellness. Post-hoc tests were conducted to evaluate the pair-wise differentials of movement and significance for wellness ratings. Notable findings included significantly $(p<0.05)$ less player load, low-intensity distance, medium-intensity distance, high-intensity distance, total distance, and acceleration and deceleration distance at all intensities, in those reporting more favorable (4-5) ratings of perceived fatigue and soreness on Sunday. Conversely, individuals reporting more favorable Sunday perceived stress ratings demonstrated significantly $(p<0.05)$ higher player load, low-intensity and medium-intensity distance, total distance, low-intensity and mediumintensity deceleration distance, and acceleration distance at all intensities than individuals reporting less favorable (1-2) perceived stress ratings. Data from the present study provide a novel investigation of perceived wellness associated with college football practice and competition. Results support the use of wellness questionnaires for monitoring perceived wellness in NCAA division I college football players.

Key Words: GPS, Monitoring, Questionnaire, American football 


\section{INTRODUCTION}

3

American football is a full-contact team sport associated with intense physical demands, characterized by frequent collisions and blunt force trauma associated with repeated contact with opponents and the ground during blocking, tackling, and ball-carrying activities, in addition to high-speed running and frequent accelerations, decelerations, and change of direction specific impacts $(29,33,34)$. Global positioning systems (GPS) technology with integrated triaxial accelerometers (IA) have provided a means of quantifying the physical demands of training and competition in NCAA division I football $(33,34)$ and similar contact team sport $(9,23)$. Recent studies $(33,34)$ have provided novel insight into the positional movement demands associated with NCAA division I football, including the quantification of sprint distances and high-intensity accelerations and decelerations, and the frequency and intensity of positional impacts and rapid changes of direction associated with competition.

The intense nature of competition in NCAA division I football necessitates the prudent programming of in-season practice loads that maintain position-specific physical demands and minimize excessive fatigue that may be associated with maladaptation and underperformance. Consequently, the judicious monitoring of the individual physiological and psychological response, commonly referred to as internal load, to exercise loads encountered in practice and competition is vital for maximizing 
competitive performance $(1,12)$. Investigations in contact team sport, including American football, have examined potential measures of an athlete's internal load, including subjective or perceived wellness, and biochemical and neuromuscular responses to training and competition $(8,20,32)$, however ambiguity exists as to which methods are most pertinent (12).

Perceived measures of wellness are efficient, inexpensive and non-invasive to the athlete (18). Additionally, wellness measures have demonstrated sensitivity to training stress, exhibiting a dose-response relationship with exercise load (28), and may be more efficacious than objective measures in identifying internal load (28). While subjective measures have demonstrated accuracy in assessing athletes' internal response to training and competition loads, the comprehensive nature of some forms presents substantial logistical challenges in many applied settings (31). A survey of the current trends in fatigue monitoring among high-performance sport revealed $84 \%$ of the respondents used subjective questionnaires, $80 \%$ of which utilized custom designed forms consisting of 4-12 items (30). Based upon current practices and previous recommendations for athlete monitoring (14), the implementation of brief, customized questionnaires to quantify the internal response of individuals participating in teamsports is supported. 
Previous research $(8,33)$ has provided an increased understanding of the positional movement demands and the time-course of perceived recovery resulting from practice and competition NCAA division I football players. Currently, the impact of GPS-derived movement variables associated with practice and game demands on perceived wellness during the in-season competitive period remain ambiguous. A more comprehensive understanding of the perceived psychological response to the movement demands of practice and competition, will provide performance staff a model from which to plan post-game recovery modalities and program subsequent training sessions. Further, evaluating the impact of weekly in-season practice loads on perceived wellness will provide novel insight for coaches seeking to manage the deleterious effects of fatigue and optimize subsequent game-day performance.

The aims of the present study were to (a) assess post-game (Sunday) recovery to determine which GPS-derived game day variables influence post-game perceived wellness in NCAA division I football players (b) to determine which GPS-derived movement variables accumulated during in-season weekly practice sessions influence perceived wellness two days prior to NCAA division I football games (Thursday). We hypothesized that there will be significant differences in GPS-derived movement variables in NCAA division I football players who reported differential ratings of perceived wellness on both Sunday and Thursday. 
METHODS

\section{EXPERIMENTAL APPROACH TO THE PROBLEM}

Two statistical models were utilized to accomplish the aims of the present study. A

'Sunday' model examined GPS and IA derived workloads resulting from Saturday games and the subsequent perceived wellness on Sunday. The 'Thursday model' examined the impact of GPS and IA derived workloads accumulated Tuesday and Wednesday, on Thursday perceived wellness. Researchers examined GPS and IA technology data collected from players during 24 regular season practices and 12 competitions completed throughout the in-season period of an NCAA division I football season. Data in the present study were grouped at the individual level and included the following positional observations: Wide Receiver (WR): 100 (52 Sunday, 42 Thursday), Offensive Linemen (OL): 98 (51 Sunday, 47 Thursday), Running Back (RB): 70 (36 Sunday, 34 Thursday), Quarterback (QB): 24 (12 Sunday, 12 Thursday), Tight End (TE): 69 (36 Sunday, 33 Thursday), Defensive Tackle (DT): 48 (26 Sunday, 22 Thursday), Defensive End (DE): 50 (26 Sunday, 24 Thursday), Linebacker (LB): 85 (39 Sunday, 46 Thursday), and Defensive Back (DB):112 (54 Sunday, 58 Thursday).

To assess perceived wellness associated with in-season practice and competition, a custom-designed questionnaire (Figure 1) was completed by participants every day following a game (Sunday), as well as Thursday morning prior to any physical activity. 
A total of 656 observations (332 Sunday and 324 Thursday) were included in the present examination. For the purposes of examining perceived wellness associated with games, only GPS and IA data where a survey was completed the following day were included in the analysis. To determine the impact of in-season weekly practice sessions on subjective markers of perceived wellness on Thursday, only movement data where an individual completed a survey on Thursday and participated in Tuesday and Wednesday practice sessions, were included for analysis.

\section{SUBJECTS}

Thirty NCAA Division I Football Bowl Subdivision (FBS) football players (age $20.5 \pm 1.1$ years; age range $18.6-22.9$; height $187.8 \pm 6.2 \mathrm{~cm}$; and mass $107.4 \pm 18.6 \mathrm{~kg}$ ) participated in the present study. All subjects were collegiate athletes whom had been selected to participate in the football program prior to the commencement of the study. All participants in the present study completed an 8-week summer off-season physical development training program that included a full-body strength and power training program and specific skills and conditioning sessions designed to simulate the demands of NCAA division I college football practice. The present study comprises the statistical analysis of data collected as part of the day to day student athlete monitoring and testing procedures within the university's football program. Ethical approval was obtained from the university's Institutional Review Board and all subjects signed an institutionally approved informed consent document prior to participating in the study. 


\section{PROCEDURES}

Global Positioning System Units. Positional movement data were collected from 24 inseason practice sessions and 12 games using commercially available microtechnology units (OptimEye S5; Catapult Innovations, Melbourne, Australia) operating at a frequency of $10 \mathrm{~Hz}$. The units included a triaxial accelerometer (IA) which operated at $100 \mathrm{~Hz}$ and assessed the frequency and magnitude of full-body acceleration (m.second ${ }^{-}$ $\left.{ }^{2}\right)$ in three dimensions, namely, anterior-posterior, mediolateral, and vertical $(16,22)$. Prior to the commencement of each practice and game, GPS receivers were placed outside for 15 minutes to acquire a satellite signal, after which, receivers were placed in a custom designed pocket attached to the shoulder pads of the subjects. Shoulder pads were custom-fit for each individual, thereby minimizing movement of the pads during practice and competition. The GPS and IA receivers used in the present study were positioned in the center of the upper back, slightly superior to the scapulae. Subjects were outfitted with the same GPS receiver for each practice and game. Following the completion of practices and games, GPS receivers were removed from the shoulder pads, and subsequently downloaded to a computer for analysis utilizing commercially available software (Catapult Sprint 5.1, Catapult Innovations, Melbourne, Australia). Combined tri-axial accelerometer data were represented as PlayerLoad ${ }^{\mathrm{TM}}$ $(\mathrm{PL})$, which is a modified vector magnitude expressed as the square root of the sum of the squared instantaneous rates of change in acceleration in each of the three planes and divided by 100 (3). Boyd and colleagues (3) have demonstrated the laboratory 
intra-unit (0.91-1.05\% coefficient of variation [CV]) and inter-unit (1.02-1.10\% CV) reliability of PL and determined its inter-unit reliability in Australian Rules Football matches $(1.90 \% \mathrm{CV})$. Findings from other team sports including basketball, netball, and Australian football have demonstrated the ability of accelerometer derived PL to differentiate between competitive games, scrimmage games, practice drills, positional demands, and levels of competition $(2,5,24)$. Improvements in technology and sampling methodologies have increased the accuracy of data recorded via portable GPS for applied research purposes (15), and have provided a valid and reliable means of assessing activity profiles in team sports (6). Previous research (6) has demonstrated the validity of GPS, with GPS-derived distance measures within $5 \%$ of a criterion distance, and intra-unit reliability of distance measures, within $4.5 \mathrm{~m}$ (90\% Cl: 3.5-6.6 m) (6). Additionally, IA have demonstrated reliability (3) as a means of measuring physical activity across multiple players in team sports, with strong inter-unit relationships $(r=0.996-0.999)$ demonstrated during high-intensity contact team sport activity.

Movement Classification System. Movement profile classifications have been described for game analysis in American football (33) and similar contact team sports (21). The classification profile utilized in the present study was selected by the researchers to more accurately reflect the demands of American football (33). Each movement classification was coded as one of four speeds of locomotion. Low-intensity movements, such as standing, walking and jogging, were considered to be $0-12.9$ $\mathrm{km} \cdot \mathrm{h}^{-1}$, medium-intensity movements, such as striding and running, were considered to be $13.0-19.3 \mathrm{~km} \cdot \mathrm{h}^{-1}$, high-intensity movements, such as fast running for some 
positional groups, and sprinting for others, were classified as $19.4-25.8 \mathrm{~km} \cdot \mathrm{h}^{-1}$, and sprinting movements were classified as exceeding $25.8 \mathrm{~km} \cdot \mathrm{h}^{-1}$. Short duration highintensity movements, or measures of acceleration and deceleration, were classified as four groups, specifically low-intensity $\left(0-1.0 \mathrm{~m} \cdot \mathrm{s}^{-2}\right)$, medium-intensity $\left(1.1-2.0 \mathrm{~m} \cdot \mathrm{s}^{-2}\right)$, high-intensity $\left(2.1-3.0 \mathrm{~m} \cdot \mathrm{s}^{-2}\right)$, and maximal-intensity $\left(>3.0 \mathrm{~m} \cdot \mathrm{s}^{-2}\right)$.

Perceived Wellness. Players were instructed to complete a customized self-report wellness questionnaire utilizing a commercially available web-based application (CoachMePlus, Buffalo, NY) on their smartphone device, every Sunday and Thursday throughout the in-season period. No physical activity took place on Sundays, however players were required to participate in medical evaluations, and were instructed to complete the questionnaire prior to the commencement of the evaluations. On Thursdays, players were instructed to complete questionnaires prior to the morning training session. The custom designed wellness questionnaire, based upon earlier recommendations by Hooper et. al. (14) and previous implementation in Rugby League (20) evaluated six subscales, including fatigue, soreness, stress, sleep quality, sleep quantity, and mood, on a 1-5 Likert scale (Figure 1). Players were instructed to respond as to how they were currently feeling.

(1) 


\section{STATISTICAL ANALYSES}

The perceived wellness ratings and movement metrics selected for categorization in the present study, were used to perform two statistical models to achieve the two main aims. All models were assessed using movement metrics as the outcome variable.

Sunday Model: A series of multi-level mixed linear regressions were used to determine the differential effect of specific game day movement metrics on perceived wellness ratings the following day (Sunday). Categorical outcomes were used to determine less favorable responses ( 1 and 2), neutral responses (3), and more favorable (4 and 5) responses to account for the possibility of non-linear relationships with varying outcomes. Each movement metric was associated with wellness ratings in each of the six subscales. Following the regression analyses, post-hoc tests were conducted to evaluate the pair-wise differentials of movement and their significance for each wellness rating (Tables 1-2). Significance in all tests was measured at three levels; $p<0.001$, $p<0.01$, and $p<0.05$. Adjusted predictions at the means were reported with their respective 95\% confidence intervals. All statistical analyses were performed using Stata Statistical/Data Analysis Software (Stata 14 for Windows, version 14.1; StataCorp, College Station, TX, USA). 
Thursday Model: A series of multi-level mixed linear regressions were used to determine the differential cumulative effects of specific movement metrics associated with Tuesday and Wednesday practice sessions on Thursday perceived wellness. Categorical outcomes were used to determine less favorable responses (1 and 2), neutral responses (3), and more favorable (4 and 5) responses to account for the possibility of non-linear relationships with varying outcomes. Each movement metric was used to examine the relationship between an individual's Thursday perceived wellness rating relative to their Sunday perceived wellness rating. Following the regression analyses, post-hoc tests were conducted to evaluate the pair-wise differentials of each movement metric and its significance for each individual's Thursday wellness rating compared to Sunday (Tables 3-6). Significance in all tests was measured at three levels; $p<0.001, p<0.01$, and $p<0.05$. Adjusted predictions at the means are reported with their respective 95\% confidence intervals. All statistical analyses were performed using Stata Statistical/Data Analysis Software (Stata 14 for Windows, version 14.1; StataCorp, College Station, TX, USA).

\section{RESULTS}

Sunday Perceived Wellness: Significant $(\mathrm{p}<0.05)$ differences in $\mathrm{PL}$, low-, medium-, highintensity distance and total distance, including acceleration and deceleration distance at all intensities resulting from competitive games on the preceding day, were demonstrated in players who rated their level of fatigue and soreness a 1 or 2 , 
compared to those who rated it a 3 , and those who rated it a 4 or 5 . Significant $(p<0.05)$ differences in sprint distance were also demonstrated in those who rated fatigue a 4 or 5 compared to those who rated fatigue a 1 or 2 (Table 1 ).

Individuals who reported a 3, 4, or 5 for perceived stress the day following competition demonstrated significantly $(p<0.05)$ greater PL, low-, medium-intensity, and total distance, low- and medium-intensity deceleration distance, and medium- and highintensity-acceleration distance than those who rated perceived stress a 1 or 2 (Table 2).

The only significant $(p<0.05)$ findings for the subscale of sleep quality were for maximalintensity deceleration distance between those whose ratings were a 1 or 2 vs a 3 , and those who rated sleep quality a 1 or 2 vs. a 4 or 5 (Table 2). No significant differences in movement variables were demonstrated for subscales of mood and sleep quantity.

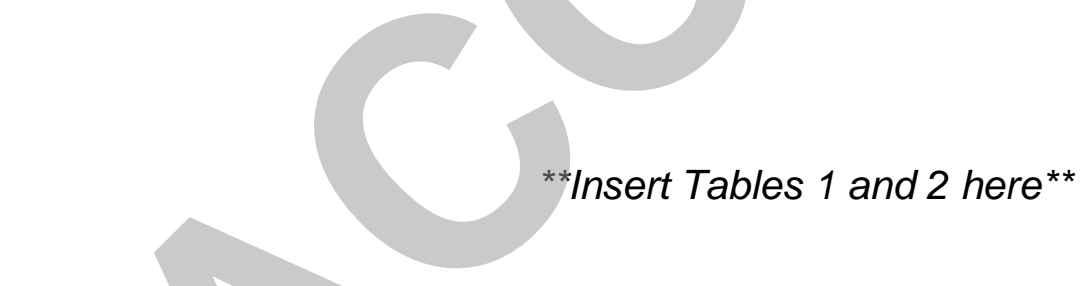

Thursday Perceived Wellness: Individuals who rated their perceived fatigue a 4 or 5 on both Sunday and Thursday accumulated significantly $(p<0.05)$ less high-intensity deceleration and maximal-intensity acceleration distance on Tuesday and Wednesday practices than those who rated fatigue a 1 or 2 on Sunday and improved to a 3 on 
Thursday, and those who reported a 1, 2, or 3 on Sunday and improved to 4 or 5 on Thursday (Table 3).

When comparing players whose rating of perceived soreness improved from Sunday to Thursday, those who rated soreness a 4 or 5 on Thursday, accumulated significantly $(p<0.05)$ more PL on Tuesday and Wednesday than those who rated soreness a 3 on Thursday. Individuals whose perceived soreness was a 3 on Thursday and the same or higher score on Sunday achieved significantly $(p<0.05)$ less PL than those whose perceived rating of soreness was a 3 on Thursday but lower (1 or 2) on Sunday. Players who rated soreness a 4 or 5 on both Sunday and Thursday had significantly $(p<0.05)$ higher cumulative PL resulting from Tuesday and Wednesday practices than those who rated soreness a 4 or 5 on Thursday and a 1,2, or 3 on Sunday. Significantly $(p<0.05)$ more total-, maximal- and high-intensity acceleration and deceleration distance was accumulated on Tuesday and Wednesday by those who rated soreness a 4 or 5 on both Sunday and Thursday, compared to those whose rating was a 3 on Thursday and the same or higher on Sunday (Table 4).

Players who rated perceived stress a 4 or 5 on both Sunday and Thursday accumulated significantly $(\mathrm{p}<0.05)$ greater $\mathrm{PL}$, total-, sprint- and maximal-acceleration and deceleration distance on Tuesday and Wednesday than those who rated stress a 1, 2, or 3 on Sunday and improved to a 4 or 5 on Thursday, and those who rated stress a 3, 4, or 5 on Sunday and increased to a 3 on Thursday. Individuals who rated perceived 
stress a 4 or 5 on both Sunday and Thursday achieved significantly $(p<0.05)$ less total distance on Tuesday and Wednesday than those whose perceived stress was a 1 or 2 on Thursday and the same or higher on Sunday (Table 5). Players who rated sleep quality a 4 or 5 on both Sunday and Thursday accrued significantly $(p<0.05)$ more sprint distance on Tuesday and Wednesday practice sessions than those who rated sleep quality a 3 on Thursday and a 1 or 2 on Sunday (Table 6).

\section{**Insert Tables 3-6 here}

\section{DISCUSSION}

The aims of the present study were to assess recovery, utilizing a custom questionnaire, to determine which GPS-derived game-day variables influenced perceived wellness the following day, and to determine the impact of in-season weekly practice sessions on subjective markers of perceived wellness two days prior to games. The results of the present study contribute novel insight into the perceived wellness associated with practice and competitive loads experienced by NCAA division I college football players throughout in-season period and the implementation of wellness questionnaires within an applied, high-performance setting. The results confirm our hypothesis that differences in perceived wellness were associated with significant differences in individual movement characteristics attributed to practice and competition. The most notable findings were significantly $(p<0.05)$ less $P L$, low-intensity, medium- 
intensity, high-intensity, and total distance, and acceleration and deceleration distance at all intensities, associated with competition, in those with more favorable ratings of perceived fatigue and soreness the day following games. Additionally, individuals who reported more favorable perceived stress the day following competition demonstrated significantly $(p<0.05)$ greater PL, low-intensity, medium-intensity, and total distance, low-intensity and medium-intensity deceleration distance, and acceleration distance at all intensities than individuals who reported the least favorable ratings of perceived stress. Data from the present study provide an increased understanding of the impact of specific game-day movement variables on post-game perceptual wellness, and support the implementation of a perceived wellness questionnaire to quantify perceptual recovery following NCAA division I football games.

Individuals who accrued significantly $(p<0.05)$ less $P L$, running distance at all intensities, and deceleration and acceleration distance at all intensities during NCAA division I football games, reported more favorable ratings of perceived fatigue the day following the game. Similar findings with respect to perceived soreness the day following games were demonstrated by significantly $(p<0.05)$ less $P L$, running distance at all intensities, except for sprint distance, and acceleration and deceleration at all intensities in individuals who reported more favorable ratings. Individuals who reported more favorable perceived stress responses the day following games demonstrated significantly $(p<0.05)$ greater movement demands associated with competition than those who rated perceived stress less favorably. The results of the present study suggest that increased movement demands resulting from competition may be directly 
associated with a less favorable perceived fatigue and soreness response the day following games. The perceived stress response appears to differ from both the fatigue and soreness response, resulting in more favorable perceived stress responses associated with increased movement demands. These data illustrate that movement characteristics associated with NCAA division I football games reflect individual perceptions of fatigue, soreness, and stress, and support the integration of perceived wellness measures as part of a comprehensive athlete monitoring program.

The high-intensity movement demands, and the frequency and intensity of positional impacts and rapid changes of direction that characterize participation in NCAA division I football games have been reported, are associated with substantial physical demands, and may contribute to increased fatigue and soreness following games $(33,34)$. Comparing the results of the present study with previous examinations is problematic due to the paucity of similar investigations in NCAA division I football. An examination by Fullagar et.al. (8) of the time course of perceptual recovery following NCAA division I football games demonstrated less favorable ratings of perceived soreness and overall wellness that persisted for up to four days following competition. While the results of Fullagar et. al. (8) shed new light on perceptions of wellness associated with NCAA division I football seasons, it did not examine perceived wellness the day following competition or quantify the game day movement demands associated with the wellness response. 
Similar findings of increased perceived soreness and fatigue one day following contact team-sport competition have been demonstrated by researchers $(20,32)$ who utilized a questionnaire similar to the one in the present study, and reported significant $(p<0.01)$ increases in fatigue and soreness ratings one day following Rugby League competition, when compared to pre-competition values. The scope of these studies, however, did not include the utilization of microtechnology to assess competitive movement demands to determine which GPS-derived movement variables may influence the differential ratings of perceived wellness the following day. While fatigue and soreness following intense team-sport competition may be expected, the present study represents a novel investigation into which GPS-derived gameday movement variables influence perceived wellness the following day. As part of a judicious athlete monitoring program, the objective quantification of external loads associated with practice and competition, alongside a subjective quantification of the athlete's physiological and psychological response to these loads, appears prudent (12). Clear guidelines on the modification of training loads in response to unfavorable perceptual responses do not exist (17), and as such performance coaches should judiciously monitor the perceptual responses of athletes following competition and take appropriate measures including the implementation of recovery protocols and the modification of subsequent practice session when deemed prudent.

In the present study, several GPS-derived variables were able to differentiate individuals whose rating of perceptual stress was a 4 or 5 vs. a 1 or 2 , and those who rated stress a 3 vs. a 1 or 2 . Data indicated more favorable perceived stress responses 
with increases in game-day exercise demands. These findings are in agreement with the results reported by Hartwig et. al. (13) which demonstrated an inverse relationship between training volumes and perceptual stress ratings in Rugby Union players during the in-season period, but are in contrast with pre-season research (4) in Australian rules football which demonstrated a negative effect of increased training loads on perceived stress ratings the following day. These data may indicate a directional relationship between the perceptual stress response and movement demands associated with intensified pre-season training camps in contact team-sport athletes, and an inverse relationship for competitive games, perhaps due to psychological factors unaccounted for, including self-satisfaction (13). In division I college football players, both physical and psychological stress have been associated with injury occurrence $(19,25)$, and consequently, the inclusion of the stress subscale as part of the athlete wellness monitoring program may be advantageous in decreasing the likelihood of maladaptation resulting from all sources of stress accompanying participation in division I college football.

The present study also investigated perceptual wellness two days prior to games to evaluate the time-course of perceived recovery and to assess the impact of in-season weekly practice sessions on subjective markers of perceived wellness preceding competition. While several significant unidirectional relationships were demonstrated between GPS-derived movement demands of competition and perceived fatigue on Sunday, similar significant unidirectional relationships were not established when examining the impact of Tuesday and Wednesday practice sessions on Thursday 
perceived fatigue. Individuals who accumulated significantly $(p<0.05)$ greater mediumintensity and high-intensity deceleration and medium-intensity and maximal-intensity acceleration distance on Tuesday and Wednesday practice sessions experienced an improvement, indicated by higher scores, in perceived fatigue on Thursday. These improvements were seen in individuals who rated perceived fatigue a 1 or 2 on Sunday and improved to a 3 on Thursday, and those who were a 1, 2 or 3 on Sunday and improved to a 4 or 5 on Thursday, when compared to individuals who rated perceived fatigue a 4 or 5 on both Sunday and Thursday. The results of Thursday assessments of perceived fatigue in the present study are supported by previous research (13) in Rugby Union players which demonstrated more favorable recovery scores in players who had the highest training and physical activity volumes during the in-season period. Data from the present study suggest that individuals with more unfavorable, or lower, ratings of perceived fatigue on Sundays are not hindered by increased practice loads on Tuesday and Wednesday, but may actually experience improvements in perceived fatigue ratings on Thursday. It is also plausible to assume that individuals who experienced increased perceived fatigue on Sundays following games may have engaged in recovery modalities in conjunction with programmed physical activities, resulting in more favorable perceived fatigue ratings on Thursday.

A lack of unidirectional findings of Thursday perceived wellness was demonstrated for the subscales of perceived soreness and stress. Individuals who rated perceived soreness a 4 or 5 on both Sunday and Thursday accumulated significantly $(p<0.05)$ greater $\mathrm{PL}$, high-intensity deceleration distance and maximal-acceleration distance in 
400

401

402

403

404

405

406

407

408

409

410

411

412

413

414

415

416

417

Tuesday and Wednesday practice sessions than those whose soreness rating improved from Sunday to Thursday, and those whose rating was the same or became worse from Sunday to Thursday. Similar to soreness, the subscale of stress demonstrated significantly $(p<0.05)$ greater PL, total, high-intensity, and sprint distance, and maximaland high-intensity acceleration and deceleration distance for individuals rating perceived stress a 4 or 5 on both Sunday and Thursday than those whose perceived stress improved from Sunday to Thursday, and those whose rating was the same or became worse from Sunday to Thursday. Limited research (8) in NCAA division I college football players makes comparison of the present study with previous investigations problematic. It is unclear whether differences in practice loads in the present study were responsible for improvements demonstrated in some wellness subscales, or if other factors including days until competition and under-reporting unfavorable responses (7) in attempt to appear better or more well-adjusted, played a role. An examination (10) of in-season perceptual wellness in Australian football players has indicated that days-to-game was a significant coefficient for wellness. Similar results have been demonstrated in Rugby League players (20) with shorter micro-cycles between competition being associated with improved wellness, suggesting that players' perception of wellness is related to days-to-game. Psychological factors, including motivation and focus of an athlete on the impending game, may override negative physiological symptoms, resulting in players perceiving themselves as recovered and physically prepared for competition (11). The possibility of these results being confounded via conscious bias associated with Thursday questionnaires cannot be underestimated. This is often the result of an individual responding in a socially 
desirable manner, typically over-reporting positive responses and under-reporting negative or unfavorable responses (27). In a college football player, this may manifest as overrating wellness on Thursday in attempt present their physical state more favorably to the coaching staff, despite possible negative physical symptoms associated with the cumulative loading of the Tuesday and Wednesday practice sessions. It is plausible that these factors may have contributed to the lack of unidirectional findings associated with the Thursday questionnaires, however similar investigations have not been undertaken in NCAA division I college football players

The results of the present study provide novel insight to the physical and psychological responses associated with participation in NCAA division I football games and inseason practice sessions. Significant differences in volumes and intensities of GPS and IA movement variables were reported in athletes who responded more or less favorably on perceived wellness measures. The use of a customized wellness questionnaire may provide sport and performance coaches with an improved understanding of the individual response to practice and competition, and contribute to the design of training and recovery protocols to enhance subsequent competitive performance. The ease of administration and cost effectiveness associated with individual athlete monitoring via wellness questionnaires, permits football teams, at every level, to implement these strategies throughout the in-season period. 
444 Future studies should examine how coaches seeking to enhance competitive

445

446

447

448

449

450

451

452

453 performance, can manipulate individual and position-specific practice volumes and intensities to mitigate fatigue, enhance recovery, and optimize subsequent competitive performance. Although it was beyond the scope of the present study, future investigations should also examine the impact of perceived wellness ratings on competitive performance and injury risk in NCAA division I football players.

\section{PRACTICAL APPLICATIONS}

The present study provided a novel analysis of the physiological and psychological response to competitive movement demands and training loads associated with inseason weekly practice sessions. Results support the implementation of a questionnaire consisting of 4 subscales, including fatigue, soreness, stress, and sleep quality. A Likert scale with five response choices, or alternatively, having individuals compare their current well-being to normal (worse than normal, normal, better than normal) offering three response choices, similar to the DALDA (26) may be employed. Consideration as to the number of questions and potential responses which ease the time burden on the athlete, while simultaneously obtaining valuable data, is critically important. 
Due to weekly competition associated with an NCAA football season, performance coaches should monitor individual perceived wellness on a weekly basis. Recovery modalities should be implemented for individuals reporting less than favorable ratings of fatigue and soreness one day following games. Additionally, an assessment of perceived wellness should be undertaken within 48 hours prior to subsequent competition, to examine the impact of weekly practice sessions on the well-being of college football players. Results of the present study do not support practice load reductions on Tuesday and Wednesday in attempts to improve well-being on Thursday, even for players who reported less than favorable ratings of wellness on Sunday. However, coaches should evaluate individual wellness scores prior to games, and initiate communication with athletes who report unfavorable wellness scores on Thursdays. Interpersonal communication conveys a sense of concern for the player, ensuring the athlete that wellness scores are being monitored and their input is meaningful, and provides coaches increased information from which to program training loads and recovery modalities for individuals who report less than favorable wellness ratings on Thursdays. Minimizing the deleterious effects of fatigue while simultaneously improving the position-specific technical, tactical, and physical demands associated with athlete preparation in division I college football players requires a collaborative effort between members of the coaching staff, medical staff, performance staff, and most importantly, the athletes themselves. The ease of administration, cost-effectiveness, and the minimal time investment required to collect perceived wellness data, makes it a practical tool for monitoring team sport athletes. 
No grant aid or manufacturer's aid was received in conjunction with the present study, and no conflicts of interest are declared. The results of this study do not constitute endorsement of the product by the authors of the National Strength and Conditioning Association.

\section{REFERENCES}

1. Borresen, $\mathrm{J}$ and Lambert, MI. The quantification of training load, the training response and the effect on performance. Sports Med 39: 779-795, 2009.

2. Boyd, LJ, Ball, K, and Aughey, RJ. Quantifying external load in Australian football matches and training using accelerometers. Int J Sports Physiol Perform 8: 44-51, 2013.

3. Boyd, LJ, Ball, K, and Aughey, RJ. The reliability of minimaxx accelerometers for measuring physical activity in Australian football. Int J Sports Physiol Perform 6: $311-321,2011$.

4. Buchheit, M, Racinais, S, Bilsborough, JC, Bourdon, PC, Voss, SC, Hocking, J, Cordy J, Mendez-Villanueva, A, and Coutts, AJ. Monitoring fitness, fatigue and running performance during a pre-season training camp in elite football players. $J$ Sci Med Sport 16: 550-555, 2013. 
5. Chandler, PT, Pinder, SJ, Currn, JD, and Gabbett, TJ. Physical demands of training and competition in collegiate netball players. J Strength Cond Res 28: 2732-2737, 2014.

6. Coutts, AJ, and Duffield, R. Validity and reliability of GPS devices for measuring movement demands of team sports. J Sci Med Sport 13: 133-135, 2010.

7. Ekegren, CL, Donaldson, A, Gabbe, BJ, and Finch, CF. Implementing injury surveillance systems alongside injury prevention programs: evaluation of an online surveillance system in a community setting. Inj Epidemio/1:19, 2014.

8. Fullagar, HK, Govus, A, Hanisch, J, and Murray, A. The time course of perceptual recovery markers following match play in division $\mathrm{I}$-a collegiate footballers. Int $\mathrm{J}$ Sports Physiol Perform 0: 1-11, 2016.

9. Gabbett, TJ, Jenkins, DG, and Abernethy, B. Physical demands of professional rugby league training and competition using microtechnology. J Sci Med Sport 15: 80-86, 2011.

10. Gallo, TF, Cormack, SJ, Gabbett, TJ, and Lorenzen, CH. Self-reported wellness profiles of professional Australian football players during the competition phase of the season. J Strength Cond Res 31: 495-502, 2017.

11. Gastin, PB, Meyer, D, and Robinson, D. Perceptions of wellness to monitor adaptive responses to training and competition in elite Australian football. J Strength Cond Res 27: 2518-2526, 2013.

12. Halson, SL. Monitoring training load to understand fatigue in athletes. Sports Med 44: 139-147, 2014. 
531

532

533

534

535

536

537

13. Hartwig, TB, Naughton, G, and Searl, J. Load, stress, and recovery in adolescent rugby union players during a competitive season. J Sports Sci 27: 1087-1094, 2009.

14. Hooper, SL, and Mackinnon, LT. Monitoring overtraining in athletes, recommendations. Sports Med 20: 321-327, 1995.

15. Johnston, RD, Gabbett, TJ, and Jenkins, DG. Applied sports science of Rugby League. Sports Med 44: 1087-1100, 2014.

16. Krasnoff, JB, Kohn, MA, Choy, FKK, Doyle, J, Johansen, K, and Painter, PL. Interunit and intraunit reliability of the RT3 triaxial accelerometer. J Phys Act Health 5: 527-538, 2008.

17. Lambert, MI, and Borresen, J. A theoretical basis of monitoring fatigue: a practical approach for coaches. Int J Sports Sci Coach 1: 371-388, 2006.

18. Main, $L$ and Grove, JR. A multi-component assessment model for monitoring training distress among athletes. Eur J Sport Sci 9: 195-202, 2009.

19. Mann, BJ, Bryant, KR, Johnstone, B, Ivey, PA, and Sayers, SP. Effect of physical and academic stress on illness and injury in division I college football players. $J$ Strength Cond Res 30: 20-25, 2016.

20. McLean, DB, Coutts, AJ, Kelly, V, McGuigan, MR, and Cormack, SJ. Neuromuscular, endocrine, and perceptual fatigue responses during different length between-match microcycles in professional rugby league players. Int J Sports Physiol Perform 5: 367-383, 2010.

21. McLellan, CP, Coad, S, Marsh, D, and Lieschke, M. Performance analysis of Super15 Rugby match-play using portable micro-technology. J Ath/ Enhanc 2:5, 2013. 
22. McLellan, CP, Lovell, DI, and Gass, GC. Biochemical and endocrine responses to impact and collision during elite Rugby League match play. J Strength Cond Res 25: 1553-1562, 2011.

23. McLellan, CP, Lovell, DI, and Gass, GC. Performance analysis of elite rugby league match play using global positioning systems. J Strength Cond Res 25:1703-1710, 2011.

24. Montgomery, PG, Pyne, DB, and Minahan, CL. The physical and physiological demands of basketball training and competition. Int J Sports Physiol Perform 5: 7586, 2010.

25. Petrie, TA. The moderating effects of social support and playing status on the life stress-injury relationship. J App/ Sport Psycho/ 5: 1-16, 1993.

26. Rushall, BS. A tool for measuring stress tolerance in elite athletes. J Appl Sport Psychol 2: 51-66, 1990.

27. Saw, AE, Main, LC, and Gastin, PB. Monitoring athletes through self-report: factors influencing implementation. J Sports Sci Med 14: 137-146, 2015.

28. Saw, AE, Main, LC, and Gastin, PB. Monitoring the athlete training response: subjective self-reported measures trump commonly used objective measures: a systematic review. Br J Sports Med 0: 1-13, 2015.

29. Sterczala, AJ, Flanagan, SD, Looney, DP, Hooper, DR, Szivak, TK, Comstock, BA, White, MT, Dupont. WH, Martin, GJ, Volek, JS, Maresh, CM, and Kraemer, WK. Similar hormonal stress tissue damage in response to national collegiate athletic association (NCAA) division I football games played in consecutive seasons. $J$ Strength Cond Res 28: 3234-3238, 2014. 
576 30. Taylor, KL, Chapman, DW, Cronin, JB, Newton, MJ, and Gill, N. Fatigue monitoring 577 in high performance sport: a survey of current trends. J Aust Strength Cond 20: 12$578 \quad 23,2012$.

579 31. Twist, $\mathrm{C}$ and Highton, J. Monitoring fatigue and recovery in rugby league players. Int J Sports Physiol Perform 8: 467-474, 2013.

32. Twist, C, Waldron, M, Highton, J, Burt, D, and Daniels, M. Neuromuscular, biochemical and perceptual post-match fatigue in professional rugby league forwards and backs. J Sports Sci 30: 359-367, 2012.

33. Wellman, AW, Coad, SC, Goulet, GC, and McLellan, CP. Quantification of competitive game demands of NCAA division I college football players using global positioning systems. J Strength Cond Res 30:11-19, 2016.

34. Wellman, AW, Coad, SC, Goulet, GC, Coffey, VG, and McLellan, CP. Quantification of accelerometer derived impacts associated with competitive games in NCAA division I college football players. J Strength Cond Res 31: 330-338, 2017. 
Table 1. Sunday Ratings of Perceived Fatigue and Soreness: Line 1: Adjusted Predictions at the Means Line 2: Lower and Upper limits of 95\% Confidence Interval

${ }^{A}$ Significantly different $(p<0.05)$ for 1 or $2 .{ }^{B}$ Significantly different $(p<0.05)$ for 3 .

All distance measures are represented as meters.

\begin{tabular}{|c|c|c|c|c|c|c|}
\hline \multicolumn{4}{|c|}{ Perceived Fatigue } & \multicolumn{3}{|c|}{ Perceived Soreness } \\
\hline $\begin{array}{c}\text { Movement } \\
\text { Variables }\end{array}$ & 1 or 2 & 3 & 4 or 5 & 1 or 2 & 3 & 4 or 5 \\
\hline Total Distance & $\begin{array}{c}3839.6 \\
(3686.1,3993.1)\end{array}$ & $\begin{array}{c}3554.9^{A} \\
(3426.2,3683.5)\end{array}$ & $\begin{array}{c}3114.1^{A B} \\
(2816.2,3412.0)\end{array}$ & $\begin{array}{c}3817.9 \\
(3694.1,3941.8)\end{array}$ & $\begin{array}{c}3441.1^{A} \\
(3426.2,3683.5)\end{array}$ & $\begin{array}{c}3064.7^{\mathrm{AB}} \\
(2816.2,3412.0)\end{array}$ \\
\hline $\begin{array}{l}\text { Low-Intensity } \\
\text { Distance }\end{array}$ & $\begin{array}{c}3221.4 \\
(3103.5,3339.3)\end{array}$ & $\begin{array}{c}2988.8^{A} \\
(2890.0,3087.6)\end{array}$ & $\begin{array}{c}2665.2^{A B} \\
(2436.4,2894.0)\end{array}$ & $\begin{array}{c}3201.6 \\
(3106.7,3296.6)\end{array}$ & $\begin{array}{c}2908.5^{A} \\
(2789.1,3027.8)\end{array}$ & $\begin{array}{c}2594.2^{A B} \\
(2333.1,2855.4)\end{array}$ \\
\hline $\begin{array}{l}\text { Medium-Intensity } \\
\text { Distance }\end{array}$ & $\begin{array}{c}391.7 \\
(364.8,418.6)\end{array}$ & $\begin{array}{c}361.4 \\
(338.9,383.9)\end{array}$ & $\begin{array}{c}293.0^{A B} \\
(240.8,345.2)\end{array}$ & $\begin{array}{c}387.2 \\
(365.4,409.1)\end{array}$ & $\begin{array}{c}347.4^{A} \\
(319.9,374.9)\end{array}$ & $\begin{array}{c}304.3^{A} \\
(244.1,364.4)\end{array}$ \\
\hline $\begin{array}{l}\text { High-Intensity } \\
\text { Distance }\end{array}$ & $\begin{array}{c}162.7 \\
(146.5,178.9)\end{array}$ & $\begin{array}{c}149.8 \\
(136.2,163.4)\end{array}$ & $\begin{array}{c}114.0^{A B} \\
(82.5,145.5)\end{array}$ & $\begin{array}{c}167.2 \\
(154.1,180.3)\end{array}$ & $\begin{array}{c}134.2^{A} \\
(117.7,150.6)\end{array}$ & $\begin{array}{c}115.3^{A} \\
(79.3,151.3)\end{array}$ \\
\hline $\begin{array}{l}\text { Sprinting } \\
\text { Distance }\end{array}$ & $\begin{array}{c}60.2 \\
(50.9,69.5)\end{array}$ & $\begin{array}{c}50.8 \\
(42.9,58.6)\end{array}$ & $\begin{array}{c}34.5^{A} \\
(16.4,52.6)\end{array}$ & $\begin{array}{c}58.1 \\
(50.5,65.6)\end{array}$ & $\begin{array}{c}46.5 \\
(37.0,56.1)\end{array}$ & $\begin{array}{c}44.1 \\
(23.3,65.0)\end{array}$ \\
\hline Player Load & $\begin{array}{c}441.3 \\
(425.7,456.9)\end{array}$ & $\begin{array}{c}411.8^{A} \\
(398.8,424.9)\end{array}$ & $\begin{array}{c}365.5^{\mathrm{AB}} \\
(335.2,395.7)\end{array}$ & $\begin{array}{c}441.0 \\
(428.5,453.5)\end{array}$ & $\begin{array}{c}398.2^{A} \\
(382.5,414.0)\end{array}$ & $\begin{array}{c}355.2^{A B} \\
(320.8,389.6)\end{array}$ \\
\hline $\begin{array}{l}\text { Low-Intensity } \\
\text { Accel. Distance }\end{array}$ & $\begin{array}{c}1740.5 \\
(1668.3,1812.7)\end{array}$ & $\begin{array}{c}1610.7^{A} \\
(1550.2,1671.2)\end{array}$ & $\begin{array}{c}1395.3^{A B} \\
(1255.1,1535.4)\end{array}$ & $\begin{array}{c}1727.4 \\
(1669.2,1785.7)\end{array}$ & $\begin{array}{c}1567.7^{A} \\
(1494.4,1640.9)\end{array}$ & $\begin{array}{c}1351.7^{A B} \\
(1191.4,1511.9)\end{array}$ \\
\hline $\begin{array}{l}\text { Medium-Intensity } \\
\text { Accel. Distance }\end{array}$ & $\begin{array}{c}101.7 \\
(96.1,107.3)\end{array}$ & $\begin{array}{c}91.8^{A} \\
(87.1,96.5)\end{array}$ & $\begin{array}{c}73.8 \mathrm{AB} \\
(63.0,84.6)\end{array}$ & $\begin{array}{c}100.8 \\
(96.3,105.3)\end{array}$ & $\begin{array}{c}87.4^{\mathrm{A}} \\
(81.7,93.1)\end{array}$ & $\begin{array}{c}73.9^{A B} \\
(61.5,86.4)\end{array}$ \\
\hline $\begin{array}{l}\text { High-Intensity } \\
\text { Accel. Distance }\end{array}$ & $\begin{array}{c}52.4 \\
(49.4,55.3)\end{array}$ & $\begin{array}{c}48.2 \\
(45.8,50.7)\end{array}$ & $\begin{array}{c}39.5^{\mathrm{AB}} \\
(33.8,45.2)\end{array}$ & $\begin{array}{c}52.5 \\
(50.1,54.9)\end{array}$ & $\begin{array}{c}45.3^{A} \\
(42.3,48.3)\end{array}$ & $\begin{array}{c}40.7^{\mathrm{A}} \\
(34,2,47.3)\end{array}$ \\
\hline $\begin{array}{l}\text { Max-Intensity } \\
\text { Accel. Distance }\end{array}$ & $\begin{array}{c}74.8 \\
(70.6,78.9)\end{array}$ & $\begin{array}{c}69.2 \\
(65.7,72.7)\end{array}$ & $\begin{array}{c}59.3^{A B} \\
(51.2,67.3)\end{array}$ & $\begin{array}{c}75.2 \\
(71.8,78.5)\end{array}$ & $\begin{array}{c}65.0^{A} \\
(60.8,69.2)\end{array}$ & $\begin{array}{c}61.0^{A} \\
(51.8,70.2)\end{array}$ \\
\hline $\begin{array}{l}\text { Low-Intensity } \\
\text { Decel. Distance }\end{array}$ & $\begin{array}{c}1102.6 \\
(1054.8,1150.5)\end{array}$ & $\begin{array}{c}1014.5^{A} \\
(974.3,1054.6)\end{array}$ & $\begin{array}{c}879.6^{A B} \\
(786.7,972.6)\end{array}$ & $\begin{array}{c}1093.2 \\
(1054.5,1131.9)\end{array}$ & $\begin{array}{c}984.9^{A} \\
(936.2,1033.5)\end{array}$ & $\begin{array}{c}859.2^{A B} \\
(752.8,965.6)\end{array}$ \\
\hline $\begin{array}{l}\text { Medium-Intensity } \\
\text { Decel. Distance }\end{array}$ & $\begin{array}{c}72.5 \\
(67.9,77.0)\end{array}$ & $\begin{array}{c}65.6^{\mathrm{A}} \\
(61.8,69.4)\end{array}$ & $\begin{array}{c}52.2^{A B} \\
(43.4,61.0)\end{array}$ & $\begin{array}{c}72.3 \\
(68.6,76.9)\end{array}$ & $\begin{array}{c}61.7^{A} \\
(57.1,66.3)\end{array}$ & $\begin{array}{c}53.0^{\mathrm{AB}} \\
(42.9,63.1)\end{array}$ \\
\hline $\begin{array}{l}\text { High-Intensity } \\
\text { Decel. Distance }\end{array}$ & $\begin{array}{c}27.4 \\
(25.4,29.5)\end{array}$ & $\begin{array}{c}24.5^{A} \\
(22.8,26.1)\end{array}$ & $\begin{array}{c}19.5^{A B} \\
(15.6,23.4)\end{array}$ & $\begin{array}{c}27.5 \\
(25.9,29.1)\end{array}$ & $\begin{array}{c}22.6^{A} \\
(20.6,24.7)\end{array}$ & $\begin{array}{c}19.8^{A} \\
(15.3,24.2)\end{array}$ \\
\hline $\begin{array}{l}\text { Max-Intensity } \\
\text { Decel. Distance }\end{array}$ & $\begin{array}{c}28.1 \\
(25.9,30.3)\end{array}$ & $\begin{array}{c}24.6^{A} \\
(22.7,26.5)\end{array}$ & $\begin{array}{c}19.3^{A B} \\
(15.0,23.7)\end{array}$ & $\begin{array}{c}27.9 \\
(26.0,29.7)\end{array}$ & $\begin{array}{c}22.7^{A} \\
(20.5,25.0)\end{array}$ & $\begin{array}{c}20.8^{A} \\
(15.8,25.7)\end{array}$ \\
\hline
\end{tabular}


Table 2. Sunday Ratings of Perceived Stress and Sleep Quality: Line 1: Adjusted Predictions at the Means Line 2: Lower and Upper limits of 95\% Confidence Interval

${ }^{A}$ Significantly different $(p<0.05)$ for 1 or $2 .{ }^{B}$ Significantly different $(p<0.05)$ for 3 .

All distance measures are represented as meters.

\begin{tabular}{|c|c|c|c|c|c|c|}
\hline \multicolumn{4}{|c|}{ Perceived Stress } & \multicolumn{3}{|c|}{ Perceived Sleep Quality } \\
\hline $\begin{array}{c}\text { Movement } \\
\text { Variables }\end{array}$ & 1 or 2 & 3 & 4 or 5 & 1 or 2 & 3 & 4 or 5 \\
\hline Total Distance & $\begin{array}{c}3314.8 \\
(3055.4,3574.3)\end{array}$ & $\begin{array}{c}3647.9^{A} \\
(3512.5,3783.3)\end{array}$ & $\begin{array}{c}3729.9^{\mathrm{A}} \\
(3551.3,3908.6)\end{array}$ & $\begin{array}{c}3761.0 \\
(3540.6,3981.4)\end{array}$ & $\begin{array}{c}3628.6 \\
(3443.4,3813.7)\end{array}$ & $\begin{array}{c}3552.1 \\
(3405.8,3698.3)\end{array}$ \\
\hline $\begin{array}{l}\text { Low-Intensity } \\
\text { Distance }\end{array}$ & $\begin{array}{c}2812.7 \\
(2613.3,3012.1)\end{array}$ & $\begin{array}{c}3070.1^{A} \\
(2966.0,3174.2)\end{array}$ & $\begin{array}{c}3126.1^{A} \\
(2988.8,3263.3)\end{array}$ & $\begin{array}{c}3160.7 \\
(2991.5,3329.9)\end{array}$ & $\begin{array}{c}3073.6 \\
(2931.5,3215.8)\end{array}$ & $\begin{array}{c}2977.9 \\
(2865.6,3090.2)\end{array}$ \\
\hline $\begin{array}{l}\text { Medium-Intensity } \\
\text { Distance }\end{array}$ & $\begin{array}{c}315.8 \\
(270.8,360.9)\end{array}$ & $\begin{array}{c}369.3^{A} \\
(3458 ., 392.8)\end{array}$ & $\begin{array}{c}385.7^{A} \\
(354.7,416.7)\end{array}$ & $\begin{array}{c}373.2 \\
(334.9,411.5)\end{array}$ & $\begin{array}{c}359.6 \\
(327.4,391.8)\end{array}$ & $\begin{array}{c}367.0 \\
(341.5,392.4)\end{array}$ \\
\hline $\begin{array}{l}\text { High-Intensity } \\
\text { Distance }\end{array}$ & $\begin{array}{c}129.6 \\
(102.4,156.7)\end{array}$ & $\begin{array}{c}153.1 \\
(138.9,167.3)\end{array}$ & $\begin{array}{c}158.6 \\
(139.9,177.3)\end{array}$ & $\begin{array}{c}164.3 \\
(141.3,187.3)\end{array}$ & $\begin{array}{c}145.5 \\
(126.2,164.8)\end{array}$ & $\begin{array}{c}148.4 \\
(133.1,163.6)\end{array}$ \\
\hline $\begin{array}{l}\text { Sprinting } \\
\text { Distance }\end{array}$ & $\begin{array}{c}52.1 \\
(36.5,67.7)\end{array}$ & $\begin{array}{c}51.7 \\
(43.5,59.8)\end{array}$ & $\begin{array}{c}54.6 \\
(43.9,65.4)\end{array}$ & $\begin{array}{c}58.2 \\
(45.1,71.4)\end{array}$ & $\begin{array}{c}46.9 \\
(35.9,58.0)\end{array}$ & $\begin{array}{c}53.8 \\
(45.1,62.5)\end{array}$ \\
\hline Player Load & $\begin{array}{c}380.2 \\
(353.9,406.4)\end{array}$ & $\begin{array}{c}419.5^{\mathrm{A}} \\
(405.8,433.2)\end{array}$ & $\begin{array}{c}435.7^{A} \\
(417.6,453.7)\end{array}$ & $\begin{array}{c}432.9 \\
(410.5,455.3)\end{array}$ & $\begin{array}{c}415.9 \\
(397.0,434.7)\end{array}$ & $\begin{array}{c}413.7 \\
(398.8,428.6)\end{array}$ \\
\hline $\begin{array}{l}\text { Low-Intensity } \\
\text { Accel. Distance }\end{array}$ & $\begin{array}{c}1510.7 \\
(1388.4,1632.9)\end{array}$ & $\begin{array}{c}1644.2 \\
(1580.4,1708.0)\end{array}$ & $\begin{array}{c}1693.9^{A} \\
(1609.8,1778.1)\end{array}$ & $\begin{array}{c}1713.4 \\
(1609.8,1817.0)\end{array}$ & $\begin{array}{c}1643.4 \\
(1556.3,1730.5)\end{array}$ & $\begin{array}{c}1602.7 \\
(1533.9,1671.5)\end{array}$ \\
\hline $\begin{array}{l}\text { Medium-Intensity } \\
\text { Accel. Distance }\end{array}$ & $\begin{array}{c}83.4 \\
(73.9,92.9)\end{array}$ & $\begin{array}{c}94.9^{A} \\
(90.0,99.9)\end{array}$ & $\begin{array}{c}97.2^{A} \\
(90.7,103.7)\end{array}$ & $\begin{array}{c}100.1 \\
(92.1,108.1)\end{array}$ & $\begin{array}{c}93.3 \\
(86.5,100.0)\end{array}$ & $\begin{array}{c}91.2 \\
(85.9,96.5)\end{array}$ \\
\hline $\begin{array}{l}\text { High-Intensity } \\
\text { Accel. Distance }\end{array}$ & $\begin{array}{c}43.2 \\
(38.3,48.2)\end{array}$ & $\begin{array}{c}49.7^{\mathrm{A}} \\
(47.1,52.3)\end{array}$ & $\begin{array}{c}50.7^{\mathrm{A}} \\
(47.2,54.1)\end{array}$ & $\begin{array}{c}50.9 \\
(46.6,55.1)\end{array}$ & $\begin{array}{c}49.2 \\
(45.7,52.8)\end{array}$ & $\begin{array}{c}47.9 \\
(45.1,50.7)\end{array}$ \\
\hline $\begin{array}{l}\text { Max-Intensity } \\
\text { Accel. Distance }\end{array}$ & $\begin{array}{c}63.2 \\
(56.3,70.2)\end{array}$ & $\begin{array}{c}71.4^{A} \\
(67.8,75.0)\end{array}$ & $\begin{array}{c}72.3 \\
(67.5,77.1)\end{array}$ & $\begin{array}{c}74.6 \\
(68.7,80.5)\end{array}$ & $\begin{array}{c}70.1 \\
(65.1,75.0)\end{array}$ & $\begin{array}{c}68.5 \\
(64.6,72.5)\end{array}$ \\
\hline $\begin{array}{l}\text { Low-Intensity } \\
\text { Decel. Distance }\end{array}$ & $\begin{array}{c}951.8 \\
(870.8,1032.9)\end{array}$ & $\begin{array}{c}1037.2 \\
(995.9,1079.5)\end{array}$ & $\begin{array}{c}1072.0^{\mathrm{A}} \\
(1016.2,1127.8)\end{array}$ & $\begin{array}{c}1059.2 \\
(990.3,1128.0)\end{array}$ & $\begin{array}{c}1036.8 \\
(978.9,1094.6)\end{array}$ & $\begin{array}{c}1023.2 \\
(977.5,1068.9)\end{array}$ \\
\hline $\begin{array}{l}\text { Medium-Intensity } \\
\text { Decel. Distance }\end{array}$ & $\begin{array}{c}58.8 \\
(51.1,66.5)\end{array}$ & $\begin{array}{c}67.8^{A} \\
(63.8,71.8)\end{array}$ & $\begin{array}{c}69.5^{\mathrm{A}} \\
(64.2,74.8)\end{array}$ & $\begin{array}{c}69.9 \\
(63.3,76.4)\end{array}$ & $\begin{array}{c}66.8 \\
(61.3,72.3)\end{array}$ & $\begin{array}{c}65.6 \\
(61.3,69.9)\end{array}$ \\
\hline $\begin{array}{l}\text { High-Intensity } \\
\text { Decel. Distance }\end{array}$ & $\begin{array}{c}21.9 \\
(18.6,25.3)\end{array}$ & $\begin{array}{c}25.7 \\
(23.9,27.4)\end{array}$ & $\begin{array}{c}25.9 \\
(23.5,28.2)\end{array}$ & $\begin{array}{c}27.0 \\
(24.2,29.9)\end{array}$ & $\begin{array}{c}24.9 \\
(22.5,27.3)\end{array}$ & $\begin{array}{c}24.3 \\
(22.4,26.2)\end{array}$ \\
\hline $\begin{array}{l}\text { Max-Intensity } \\
\text { Decel. Distance }\end{array}$ & $\begin{array}{c}22.3 \\
(18.5,26.0)\end{array}$ & $\begin{array}{c}25.6 \\
(23.7,27.6)\end{array}$ & $\begin{array}{c}26.7 \\
(24.1,29.3)\end{array}$ & $\begin{array}{c}29.1 \\
(25.9,32.3)\end{array}$ & $\begin{array}{c}24.5^{A} \\
(21.8,27.2)\end{array}$ & $\begin{array}{c}24.3^{A} \\
(22.2,26.4)\end{array}$ \\
\hline
\end{tabular}


Table 3. Thursday Ratings of Perceived Fatigue: Line 1: : Adjusted Cumulative Monday - Wednesday Practice Session Predictions at the Means Line 2: Lower and Upper limits of 95\% Confidence Interval

${ }^{A}$ Significantly different $(p<0.05)$ for 1 or 2 that were better than Sunday. ${ }^{B}$ Significantly different $(p<0.05)$ for 1 or 2 that were same or worse than Sunday. ${ }^{\mathrm{C}}$ Significantly different $(p<0.05)$ for a 3 that were better than Sunday. ${ }^{D}$ Significantly different $(p<0.05)$ for a 3 that were same or worse than Sunday.

E Significantly different $(p<0.05)$ for 4 or 5 that were better than Sunday.

All distance measures are represented as meters.

\begin{tabular}{|c|c|c|c|c|c|c|}
\hline \multirow{2}{*}{$\begin{array}{l}\text { Movement } \\
\text { Variables }\end{array}$} & \multicolumn{2}{|c|}{1 or 2 on Thursday } & \multicolumn{2}{|c|}{3 on Thursday } & \multicolumn{2}{|c|}{4 or 5 on Thursday } \\
\hline & Better than Sunday & $\begin{array}{c}\text { Same or Worse than } \\
\text { Sunday }\end{array}$ & Better than Sunday & $\begin{array}{c}\text { Same or Worse than } \\
\text { Sunday }\end{array}$ & Better than Sunday & $\begin{array}{c}\text { Same or Worse than } \\
\text { Sunday }\end{array}$ \\
\hline Total Distance & $\begin{array}{c}6349.5 \\
(5521.9,7177.0)\end{array}$ & $\begin{array}{c}6479.0 \\
(6339.8,6618.2)\end{array}$ & $\begin{array}{c}6560.7 \\
(6363.8,6757.5)\end{array}$ & $\begin{array}{c}6381.4 \\
6267.2,6495.6)\end{array}$ & $\begin{array}{c}6501.7 \\
(6280.6,6722.9)\end{array}$ & $\begin{array}{c}6194.8 \\
(5846.7,6542.8)\end{array}$ \\
\hline $\begin{array}{l}\text { Low-Intensity } \\
\text { Distance }\end{array}$ & $\begin{array}{c}5071.5 \\
(4434.6,5708.4)\end{array}$ & $\begin{array}{c}5224.6 \\
(5117.6,5331.6)\end{array}$ & $\begin{array}{c}5270.6 \\
(5119.3,5422.0)\end{array}$ & $\begin{array}{c}5110.8 \\
(5022.9,5198.7)\end{array}$ & $\begin{array}{c}5207.2 \\
(5037.2,5377.2)\end{array}$ & $\begin{array}{c}5015.4 \\
(4747.5,5283.3)\end{array}$ \\
\hline $\begin{array}{l}\text { Medium-Intensity } \\
\text { Distance }\end{array}$ & $\begin{array}{c}844.7 \\
(697.0,992.4)\end{array}$ & $\begin{array}{c}816.2 \\
(791.3,841.1)\end{array}$ & $\begin{array}{c}840.3 \\
(805.1,875.5)\end{array}$ & $\begin{array}{c}823.8 \\
(803.5,844.2)\end{array}$ & $\begin{array}{c}848.5 \\
(809.1,888.0)\end{array}$ & $\begin{array}{c}761.6^{\mathrm{EC}} \\
(699.7,823.5)\end{array}$ \\
\hline $\begin{array}{l}\text { High-Intensity } \\
\text { Distance }\end{array}$ & $\begin{array}{c}370.0 \\
(278.2,461.8)\end{array}$ & $\begin{array}{c}356.5 \\
(341.0,371.9)\end{array}$ & $\begin{array}{c}376.3 \\
(354.3,398.3)\end{array}$ & $\begin{array}{c}367.1 \\
(354.5,379.8)\end{array}$ & $\begin{array}{c}371.5 \\
(346.9,396.1)\end{array}$ & $\begin{array}{c}334.6 \\
(296.0,373.2)\end{array}$ \\
\hline $\begin{array}{l}\text { Sprinting } \\
\text { Distance }\end{array}$ & $\begin{array}{c}73.7 \\
(41.5,105.9)\end{array}$ & $\begin{array}{c}71.7 \\
(66.3,77.1)\end{array}$ & $\begin{array}{c}74.2 \\
(66.5,81.9)\end{array}$ & $\begin{array}{c}75.7 \\
(71.3,80.2)\end{array}$ & $\begin{array}{c}80.1 \\
(71.5,88.7)\end{array}$ & $\begin{array}{c}74.7 \\
(60.9,88.4)\end{array}$ \\
\hline Player Load & $\begin{array}{c}801.5 \\
(720.3,882.6)\end{array}$ & $\begin{array}{c}801.4 \\
(787.8,815.0)\end{array}$ & $\begin{array}{c}813.5 \\
(794.2,832.7)\end{array}$ & $\begin{array}{c}793.7 \\
(782.5,804.8)\end{array}$ & $\begin{array}{c}800.3 \\
(778.8,821.9)\end{array}$ & $\begin{array}{c}783.1 \\
(749.1,817.1)\end{array}$ \\
\hline $\begin{array}{l}\text { Low-Intensity } \\
\text { Accel. Distance }\end{array}$ & $\begin{array}{c}3000.2 \\
(2619.9,3380.5)\end{array}$ & $\begin{array}{c}2988.0 \\
(2923.9,3052.1)\end{array}$ & $\begin{array}{c}3026.3 \\
(2935.8,3116.8)\end{array}$ & $\begin{array}{c}2950.0 \\
(2897.5,3002.4)\end{array}$ & $\begin{array}{c}3005.4 \\
(2903.8,3107.0)\end{array}$ & $\begin{array}{c}2833.9 \\
(2673.2,2994.7)\end{array}$ \\
\hline $\begin{array}{l}\text { Medium-Intensity } \\
\text { Accel. Distance }\end{array}$ & $\begin{array}{c}191.8 \\
(165.1,218.5)\end{array}$ & $\begin{array}{c}189.9 \\
(185.3,194.4)\end{array}$ & $\begin{array}{c}193.8 \\
(187.5,200.1)\end{array}$ & $\begin{array}{c}189.7 \\
(186.0,193.4)\end{array}$ & $\begin{array}{c}193.7 \\
(186.5,200.8)\end{array}$ & $\begin{array}{c}178.8^{\mathrm{EC}} \\
(167.6,190.1)\end{array}$ \\
\hline $\begin{array}{l}\text { High-Intensity } \\
\text { Accel. Distance }\end{array}$ & $\begin{array}{c}106.2 \\
(91.2,121.3)\end{array}$ & $\begin{array}{c}105.1 \\
(102.6,107.7)\end{array}$ & $\begin{array}{c}108.4 \\
(104.8,111.9)\end{array}$ & $\begin{array}{c}104.9 \\
(102.8,106.9)\end{array}$ & $\begin{array}{c}107.9 \\
(103.9,111.9)\end{array}$ & $\begin{array}{c}101.1 \\
(94.7,107.4)\end{array}$ \\
\hline $\begin{array}{l}\text { Max-Intensity } \\
\text { Accel. Distance }\end{array}$ & $\begin{array}{c}189.4 \\
(164.8,214.0)\end{array}$ & $\begin{array}{c}185.6 \\
(181.4,189.8)\end{array}$ & $\begin{array}{c}189.9 \\
(184.0,195.7)\end{array}$ & $\begin{array}{c}185.1 \\
(181.7,188.5)\end{array}$ & $\begin{array}{c}188.3 \\
(181.8,194.9)\end{array}$ & $\begin{array}{c}175.7^{\mathrm{EC}} \\
(165.4,186.0)\end{array}$ \\
\hline $\begin{array}{l}\text { Low-Intensity } \\
\text { Decel. Distance }\end{array}$ & $\begin{array}{c}2294.9 \\
(2032.6,2557.2)\end{array}$ & $\begin{array}{c}2271.7 \\
(2227.4,2315.9)\end{array}$ & $\begin{array}{c}2304.5 \\
(2242.0,2367.0)\end{array}$ & $\begin{array}{c}2269.4 \\
(2233.2,2305.5)\end{array}$ & $\begin{array}{c}2294.9 \\
(2225.0,2364.8)\end{array}$ & $\begin{array}{c}2172.8 \\
(2061.8,2283.9)\end{array}$ \\
\hline $\begin{array}{l}\text { Medium-Intensity } \\
\text { Decel. Distance }\end{array}$ & $\begin{array}{c}173.0 \\
(147.6,198.3)\end{array}$ & $\begin{array}{c}168.7 \\
(164.4,173.0)\end{array}$ & $\begin{array}{c}173.7 \\
(167.7,179.7)\end{array}$ & $\begin{array}{c}170.2 \\
(166.7,173.7)\end{array}$ & $\begin{array}{c}172.1 \\
(165.3,178.9)\end{array}$ & $\begin{array}{c}159.0^{\mathrm{EC}} \\
(148.4,169.7)\end{array}$ \\
\hline $\begin{array}{l}\text { High-Intensity } \\
\text { Decel. Distance }\end{array}$ & $\begin{array}{c}65.0 \\
(53.5,59.7)\end{array}$ & $\begin{array}{c}63.1 \\
(61.1,65.0)\end{array}$ & $\begin{array}{c}66.0 \\
(63.2,68.7)\end{array}$ & $\begin{array}{c}63.9 \\
(62.4,65.5)\end{array}$ & $\begin{array}{c}66.0 \\
(63.0,69.1)\end{array}$ & $\begin{array}{c}59.0^{\mathrm{EC}} \\
(54.1,63.8)\end{array}$ \\
\hline $\begin{array}{l}\text { Max-Intensity } \\
\text { Decel. Distance }\end{array}$ & $\begin{array}{c}48.4 \\
(37.1,59.7)\end{array}$ & $\begin{array}{c}47.0 \\
(45.1,48.9)\end{array}$ & $\begin{array}{c}49.3 \\
(46.6,52.0)\end{array}$ & $\begin{array}{c}46.8 \\
(45.2,48.3)\end{array}$ & $\begin{array}{c}48.9 \\
(45.9,51.9)\end{array}$ & $\begin{array}{c}44.1 \\
(39.4,48.9)\end{array}$ \\
\hline
\end{tabular}


Table 4. Thursday Ratings of Perceived Soreness: Line 1: Adjusted Cumulative Monday - Wednesday Practice Session Predictions at the Means Line 2: Lower and Upper limits of 95\% Confidence Interval

${ }^{A}$ Significantly different $(p<0.05)$ for 1 or 2 that were better than Sunday. ${ }^{B}$ Significantly different $(p<0.05)$ for 1 or 2 that were same or worse than Sunday.

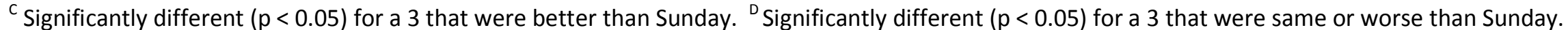

E Significantly different $(p<0.05)$ for 4 or 5 that were better than Sunday.

All distance measures are represented as meters.

\begin{tabular}{|c|c|c|c|c|c|c|}
\hline \multirow{2}{*}{$\begin{array}{l}\text { Movement } \\
\text { Variables }\end{array}$} & \multicolumn{2}{|c|}{1 or 2 on Thursday } & \multicolumn{2}{|c|}{3 on Thursday } & \multicolumn{2}{|c|}{4 or 5 on Thursday } \\
\hline & Better than Sunday & $\begin{array}{c}\text { Same or Worse than } \\
\text { Sunday }\end{array}$ & Better than Sunday & $\begin{array}{c}\text { Same or Worse than } \\
\text { Sunday }\end{array}$ & Better than Sunday & $\begin{array}{c}\text { Same or Worse than } \\
\text { Sunday }\end{array}$ \\
\hline Total Distance & $\begin{array}{c}6477.8 \\
(6211.4,6744.3)\end{array}$ & $\begin{array}{c}6490.1 \\
(6367.2,6613.1)\end{array}$ & $\begin{array}{c}6503.2 \\
(6355.5,6651.0)\end{array}$ & $\begin{array}{c}6299.8 \\
(6162.6,6437.0)\end{array}$ & $\begin{array}{c}6337.2 \\
(6101.8,6572.7)\end{array}$ & $\begin{array}{c}6689.4^{\mathrm{E}} \\
(6354.0,7024.9)\end{array}$ \\
\hline $\begin{array}{l}\text { Low-Intensity } \\
\text { Distance }\end{array}$ & $\begin{array}{c}5182.6 \\
(4977.1,5388.1)\end{array}$ & $\begin{array}{c}5222.7 \\
(5127.8,5317.6)\end{array}$ & $\begin{array}{c}5218.5 \\
(5104.6,5332.5)\end{array}$ & $\begin{array}{c}5065.5 \\
(4959.7,5171.2)\end{array}$ & $\begin{array}{c}5090.9 \\
(4909.4,5272.3)\end{array}$ & $\begin{array}{c}5344.6^{D} \\
(5086.5,5602.7)\end{array}$ \\
\hline $\begin{array}{l}\text { Medium-Intensity } \\
\text { Distance }\end{array}$ & $\begin{array}{c}834.4 \\
(786.7,882.0)\end{array}$ & $\begin{array}{c}827.8 \\
(805.8,849.8)\end{array}$ & $\begin{array}{c}833.1 \\
(806.6,859.6)\end{array}$ & $\begin{array}{c}800.9 \\
(776.4,825.4)\end{array}$ & $\begin{array}{c}810.4 \\
(768.3,852.5)\end{array}$ & $\begin{array}{c}880.1^{\mathrm{D}} \\
(820.2,940.0)\end{array}$ \\
\hline $\begin{array}{l}\text { High-Intensity } \\
\text { Distance }\end{array}$ & $\begin{array}{c}370.1 \\
(340.4,399.8)\end{array}$ & $\begin{array}{c}365.7 \\
(352.0,379.4)\end{array}$ & $\begin{array}{c}369.8 \\
(353.8,386.3)\end{array}$ & $\begin{array}{c}354.1 \\
(338.7,369.4)\end{array}$ & $\begin{array}{c}349.9 \\
(323.6,376.2)\end{array}$ & $\begin{array}{c}390.7 \\
(353.2,428.2)\end{array}$ \\
\hline $\begin{array}{l}\text { Sprinting } \\
\text { Distance }\end{array}$ & $\begin{array}{c}75.1 \\
(64.7,85.5)\end{array}$ & $\begin{array}{c}72.6 \\
(67.8,77.4)\end{array}$ & $\begin{array}{c}75.9 \\
(70.1,81.6)\end{array}$ & $\begin{array}{c}74.6 \\
(69.3,80.0)\end{array}$ & $\begin{array}{c}79.6 \\
(70.3,88.8)\end{array}$ & $\begin{array}{c}78.6 \\
(65.5,91.7)\end{array}$ \\
\hline Player Load & $\begin{array}{c}803.6 \\
(777.5,829.7)\end{array}$ & $\begin{array}{c}805.2 \\
(793.2,817.1)\end{array}$ & $\begin{array}{c}808.2 \\
(793.9,822.4)\end{array}$ & $\begin{array}{c}782.3^{\mathrm{CB}} \\
(769.0,795.6)\end{array}$ & $\begin{array}{c}781.5^{\mathrm{c}} \\
(758.7,804.3)\end{array}$ & $\begin{array}{c}829.5^{\mathrm{DE}} \\
(797.0,861.9)\end{array}$ \\
\hline $\begin{array}{l}\text { Low-Intensity } \\
\text { Accel. Distance }\end{array}$ & $\begin{array}{c}3000.7 \\
(2878.0,3123.5)\end{array}$ & $\begin{array}{c}2994.3 \\
(2937.7,3051.0)\end{array}$ & $\begin{array}{c}2996.3 \\
(2928.2,3064.5)\end{array}$ & $\begin{array}{c}2910.9 \\
(2847.7,2974.1)\end{array}$ & $\begin{array}{c}2930.7 \\
(2822.2,3039.1)\end{array}$ & $\begin{array}{c}3081.1^{D} \\
(2926.9,3235.3)\end{array}$ \\
\hline $\begin{array}{l}\text { Medium-Intensity } \\
\text { Accel. Distance }\end{array}$ & $\begin{array}{c}191.7 \\
(183.1,200.2)\end{array}$ & $\begin{array}{c}191.1 \\
(187.1,195.0)\end{array}$ & $\begin{array}{c}192.4 \\
(187.7,197.2)\end{array}$ & $\begin{array}{c}185.6 \\
(181.2,190.0)\end{array}$ & $\begin{array}{c}188.1 \\
(180.5,195.7)\end{array}$ & $\begin{array}{c}201.1^{D} \\
(190.3,212.0)\end{array}$ \\
\hline $\begin{array}{l}\text { High-Intensity } \\
\text { Accel. Distance }\end{array}$ & $\begin{array}{c}106.8 \\
(101.9,111.6)\end{array}$ & $\begin{array}{c}106.1 \\
(103.9,108.3)\end{array}$ & $\begin{array}{c}106.6 \\
(104.0,109.3)\end{array}$ & $\begin{array}{c}102.9 \\
(100.4,105.4)\end{array}$ & $\begin{array}{c}104.8 \\
(100.5,109.1)\end{array}$ & $\begin{array}{c}111.6^{\mathrm{D}} \\
(105.5,117.7)\end{array}$ \\
\hline $\begin{array}{l}\text { Max-Intensity } \\
\text { Accel. Distance }\end{array}$ & $\begin{array}{c}188.0 \\
(180.1,195.9)\end{array}$ & $\begin{array}{c}186.0 \\
(182.3,189.6)\end{array}$ & $\begin{array}{c}188.9 \\
(184.5,193.3)\end{array}$ & $\begin{array}{c}181.4^{\mathrm{C}} \\
(177.3,185.4)\end{array}$ & $\begin{array}{c}183.2 \\
(176.2,190.2)\end{array}$ & $\begin{array}{c}197.0^{\mathrm{DE}} \\
(187.0,207.0)\end{array}$ \\
\hline $\begin{array}{l}\text { Low-Intensity } \\
\text { Decel. Distance }\end{array}$ & $\begin{array}{c}2302.0 \\
(2217.5,2386.4)\end{array}$ & $\begin{array}{c}2284.3 \\
(2245.3,2323.3)\end{array}$ & $\begin{array}{c}2295.0 \\
(2248.1,2341.8)\end{array}$ & $\begin{array}{c}2230.1 \\
(2186.7,2273.6)\end{array}$ & $\begin{array}{c}2236.0 \\
(2161.4,2310.6)\end{array}$ & $\begin{array}{c}2345.7^{D} \\
(2239.3,2452.1)\end{array}$ \\
\hline $\begin{array}{l}\text { Medium-Intensity } \\
\text { Decel. Distance }\end{array}$ & $\begin{array}{c}172.2 \\
(164.0,180.3)\end{array}$ & $\begin{array}{c}170.3 \\
(166.5,174.1)\end{array}$ & $\begin{array}{c}172.2 \\
(167.7,176.7)\end{array}$ & $\begin{array}{c}165.9 \\
(161.7,170.1)\end{array}$ & $\begin{array}{c}166.8 \\
(159.6,174.0)\end{array}$ & $\begin{array}{c}179.3^{D} \\
(168.9,189.6)\end{array}$ \\
\hline $\begin{array}{l}\text { High-Intensity } \\
\text { Decel. Distance }\end{array}$ & $\begin{array}{c}64.7 \\
(60.9,68,4)\end{array}$ & $\begin{array}{c}63.6 \\
(61.9,65.3)\end{array}$ & $\begin{array}{c}65.3 \\
(63.2,67.3)\end{array}$ & $\begin{array}{c}62.5 \\
(60.6,64.4)\end{array}$ & $\begin{array}{c}62.9 \\
(59.6,66.3)\end{array}$ & $\begin{array}{c}68.9^{\mathrm{DE}} \\
(64.2,73.6)\end{array}$ \\
\hline $\begin{array}{l}\text { Max-Intensity } \\
\text { Decel. Distance }\end{array}$ & $\begin{array}{c}47.7 \\
(44.0,51.3)\end{array}$ & $\begin{array}{c}47.3 \\
(45.6,48.9)\end{array}$ & $\begin{array}{c}48.3 \\
(46.3,50.3)\end{array}$ & $\begin{array}{c}45.7 \\
(43.8,47.6)\end{array}$ & $\begin{array}{c}47.2 \\
(44.0,50.5)\end{array}$ & $\begin{array}{c}51.6^{\mathrm{D}} \\
(47.0,56.2)\end{array}$ \\
\hline
\end{tabular}


Table 5. Thursday Ratings of Perceived Stress: Line 1: Adjusted Cumulative Monday - Wednesday Practice Session Predictions at the Means Line 2: Lower and Upper limits of 95\% Confidence Interval

${ }^{A}$ Significantly different $(p<0.05)$ for 1 or 2 that were better than Sunday. ${ }^{B}$ Significantly different $(p<0.05)$ for 1 or 2 that were same or worse than Sunday.

${ }^{\mathrm{C}}$ Significantly different $(p<0.05)$ for a 3 that were better than Sunday. ${ }^{D}$ Significantly different $(p<0.05)$ for a 3 that were same or worse than Sunday.

E Significantly different $(p<0.05)$ for 4 or 5 that were better than Sunday.

All distance measures are represented as meters. (**There were no instances of individuals reporting a 1 or 2 on Thursday that were better than Sunday)

\begin{tabular}{|c|c|c|c|c|c|c|}
\hline \multirow{2}{*}{$\begin{array}{l}\text { Movement } \\
\text { Variables }\end{array}$} & \multicolumn{2}{|c|}{1 or 2 on Thursday } & \multicolumn{2}{|c|}{3 on Thursday } & \multicolumn{2}{|c|}{4 or 5 on Thursday } \\
\hline & Better than Sunday & $\begin{array}{c}\text { Same or Worse than } \\
\text { Sunday }\end{array}$ & Better than Sunday & $\begin{array}{c}\text { Same or Worse than } \\
\text { Sunday }\end{array}$ & Better than Sunday & $\begin{array}{c}\text { Same or Worse than } \\
\text { Sunday }\end{array}$ \\
\hline Total Distance & - & $\begin{array}{c}6516.1 \\
(6324.2,6708.0)\end{array}$ & $\begin{array}{c}6366.4 \\
(6114.0,6618.8)\end{array}$ & $\begin{array}{c}6394.5 \\
(6287.8,6501.2)\end{array}$ & $\begin{array}{c}6215.4^{\mathrm{B}} \\
(6028.8,6402.0)\end{array}$ & $\begin{array}{c}6649.4^{\mathrm{DE}} \\
(6454.7,6844.0)\end{array}$ \\
\hline $\begin{array}{l}\text { Low-Intensity } \\
\text { Distance }\end{array}$ & - & $\begin{array}{c}5265.6 \\
(5116.7,5414.4)\end{array}$ & $\begin{array}{c}5092.0 \\
(4896.5,5287.5)\end{array}$ & $\begin{array}{c}5151.9 \\
(5069.4,5234.5)\end{array}$ & $\begin{array}{c}5013.2^{B} \\
(4868.9,5157.6)\end{array}$ & $\begin{array}{c}5285.8^{\mathrm{E}} \\
(5135.2,5436.3)\end{array}$ \\
\hline $\begin{array}{l}\text { Medium-Intensity } \\
\text { Distance }\end{array}$ & - & $\begin{array}{c}812.1 \\
(778.1,846.1)\end{array}$ & $\begin{array}{c}831.4 \\
(786.6,876.2)\end{array}$ & $\begin{array}{c}809.0 \\
(790.1,828.0)\end{array}$ & $\begin{array}{c}758.8 \\
(752.6,819.0)\end{array}$ & $\begin{array}{c}882.0^{\mathrm{BDE}} \\
(847.3,916.6)\end{array}$ \\
\hline $\begin{array}{l}\text { High-Intensity } \\
\text { Distance }\end{array}$ & - & $\begin{array}{c}362.5 \\
(341.2,383.7)\end{array}$ & $\begin{array}{c}372.0 \\
(344.0,400.0)\end{array}$ & $\begin{array}{c}354.3 \\
(342.5,366.2)\end{array}$ & $\begin{array}{c}346.8 \\
(326.1,367.5)\end{array}$ & $\begin{array}{c}391.9^{\mathrm{DE}} \\
(370.3,413.5)\end{array}$ \\
\hline $\begin{array}{l}\text { Sprinting } \\
\text { Distance }\end{array}$ & - & $\begin{array}{c}74.2 \\
(66.7,81.6)\end{array}$ & $\begin{array}{c}76.4 \\
(66.5,86.2)\end{array}$ & $\begin{array}{c}72.4 \\
(68.2,76.6)\end{array}$ & $\begin{array}{c}68.9 \\
(61.6,76.2)\end{array}$ & $\begin{array}{c}83.5^{\mathrm{DE}} \\
(75.9,91.2)\end{array}$ \\
\hline Player Load & - & $\begin{array}{c}797.9 \\
(779.0,816.7)\end{array}$ & $\begin{array}{c}794.8 \\
(770.0,819.6)\end{array}$ & $\begin{array}{c}795.1 \\
(784.7,805.6)\end{array}$ & $\begin{array}{c}780.0 \\
(761.6,798.3)\end{array}$ & $\begin{array}{c}820.9^{\mathrm{DE}} \\
(801.9,839.9)\end{array}$ \\
\hline $\begin{array}{l}\text { Low-Intensity } \\
\text { Accel. Distance }\end{array}$ & - & $\begin{array}{c}2975.8 \\
(2886.9,3064.7)\end{array}$ & $\begin{array}{c}2949.6 \\
(2832.9,3066.3)\end{array}$ & $\begin{array}{c}2950.5 \\
(2901.0,3000.0)\end{array}$ & $\begin{array}{c}2895.4 \\
(2809.1,2981.7)\end{array}$ & $\begin{array}{c}3072.0^{\mathrm{DE}} \\
(2980.9,3163.0)\end{array}$ \\
\hline $\begin{array}{l}\text { Medium-Intensity } \\
\text { Accel. Distance }\end{array}$ & - & $\begin{array}{c}189.8 \\
(183.7,196.0)\end{array}$ & $\begin{array}{c}189.1 \\
(181.0,197.2)\end{array}$ & $\begin{array}{c}188.7 \\
(185.3,192.1)\end{array}$ & $\begin{array}{c}181.3 \\
(175.3,187.2)\end{array}$ & $\begin{array}{c}199.6^{\mathrm{DE}} \\
(193.3,205.9)\end{array}$ \\
\hline $\begin{array}{l}\text { High-Intensity } \\
\text { Accel. Distance }\end{array}$ & - & $\begin{array}{c}105.3 \\
(101.8,108.8)\end{array}$ & $\begin{array}{c}105.6 \\
(101.1,110.2)\end{array}$ & $\begin{array}{c}104.3 \\
(102.4,106.2)\end{array}$ & $\begin{array}{c}101.5 \\
(98.2,104.9)\end{array}$ & $\begin{array}{c}111.0^{\mathrm{BDE}} \\
(107.4,114.5)\end{array}$ \\
\hline $\begin{array}{l}\text { Max-Intensity } \\
\text { Accel. Distance }\end{array}$ & - & $\begin{array}{c}186.3 \\
(180.6,192.1)\end{array}$ & $\begin{array}{c}186.9 \\
(179.4,194.5)\end{array}$ & $\begin{array}{c}183.7 \\
(180.5,186.9)\end{array}$ & $\begin{array}{c}180.5 \\
(175.0,186.1)\end{array}$ & $\begin{array}{c}192.6^{\mathrm{DE}} \\
(186.8,198.4)\end{array}$ \\
\hline $\begin{array}{l}\text { Low-Intensity } \\
\text { Decel. Distance }\end{array}$ & - & $\begin{array}{c}2267.5 \\
(2206.6,2328.4)\end{array}$ & $\begin{array}{c}2254.4 \\
(2174.5,2334.3)\end{array}$ & $\begin{array}{c}2253.5 \\
(2219.7,2287.4)\end{array}$ & $\begin{array}{c}2211.6 \\
(2152.6,2270.6)\end{array}$ & $\begin{array}{c}2360.2^{\mathrm{DE}} \\
(2297.7,2422.7)\end{array}$ \\
\hline $\begin{array}{l}\text { Medium-Intensity } \\
\text { Decel. Distance }\end{array}$ & - & $\begin{array}{c}169.0 \\
(163.2,174.9)\end{array}$ & $\begin{array}{c}171.0 \\
(163.4,178.7)\end{array}$ & $\begin{array}{c}167.6 \\
(164.4,170.9)\end{array}$ & $\begin{array}{c}162.5 \\
(156.8,168.1)\end{array}$ & $\begin{array}{c}179.1^{\mathrm{BDE}} \\
(173.1,185.0)\end{array}$ \\
\hline $\begin{array}{l}\text { High-Intensity } \\
\text { Decel. Distance }\end{array}$ & - & $\begin{array}{c}63.3 \\
(60.6,65.9)\end{array}$ & $\begin{array}{c}64.2 \\
(60.6,67.7)\end{array}$ & $\begin{array}{c}63.1 \\
(61.6,64.6)\end{array}$ & $\begin{array}{c}61.4 \\
(58.7,64.0)\end{array}$ & $\begin{array}{c}67.6^{\mathrm{DE}} \\
(64.9,70.4)\end{array}$ \\
\hline $\begin{array}{l}\text { Max-Intensity } \\
\text { Decel. Distance }\end{array}$ & - & $\begin{array}{c}47.3 \\
(44.7,49.9)\end{array}$ & $\begin{array}{c}48.6 \\
(45.1,52.0)\end{array}$ & $\begin{array}{c}46.4 \\
(44.9,47.8)\end{array}$ & $\begin{array}{c}44.7 \\
(42.1,47.2)\end{array}$ & $\begin{array}{c}50.4^{\mathrm{DE}} \\
(47.7,53.0)\end{array}$ \\
\hline
\end{tabular}


Table 6. Thursday Ratings of Perceived Sleep Quality: Line 1: : Adjusted Cumulative Monday - Wednesday Practice Session Predictions at the Means Line 2: Lower and Upper limits of 95\% Confidence Interval

${ }^{A}$ Significantly different $(p<0.05)$ for 1 or 2 that were better than Sunday. ${ }^{B}$ Significantly different $(p<0.05)$ for 1 or 2 that were same or worse than Sunday. ${ }^{\mathrm{C}}$ Significantly different $(p<0.05)$ for a 3 that were better than Sunday. ${ }^{D}$ Significantly different $(p<0.05)$ for a 3 that were same or worse than Sunday.

E Significantly different $(p<0.05)$ for 4 or 5 that were better than Sunday.

All distance measures are represented as meters.

\begin{tabular}{|c|c|c|c|c|c|c|}
\hline \multirow{2}{*}{$\begin{array}{l}\text { Movement } \\
\text { Variables }\end{array}$} & \multicolumn{2}{|c|}{1 or 2 on Thursday } & \multicolumn{2}{|c|}{3 on Thursday } & \multicolumn{2}{|c|}{4 or 5 on Thursday } \\
\hline & Better than Sunday & $\begin{array}{c}\text { Same or Worse than } \\
\text { Sunday }\end{array}$ & Better than Sunday & $\begin{array}{c}\text { Same or Worse than } \\
\text { Sunday }\end{array}$ & Better than Sunday & $\begin{array}{c}\text { Same or Worse than } \\
\text { Sunday }\end{array}$ \\
\hline Total Distance & $\begin{array}{c}6501.4 \\
(5838.1,7164.8)\end{array}$ & $\begin{array}{c}6382.6 \\
(6204.6,6560.5)\end{array}$ & $\begin{array}{c}6172.8 \\
(5878.5,6467.2)\end{array}$ & $\begin{array}{c}6429.8 \\
(6298.1,6561.4)\end{array}$ & $\begin{array}{c}6454.2 \\
(6310.7,6597.7)\end{array}$ & $\begin{array}{c}6506.0 \\
(6370.8,6641.2)\end{array}$ \\
\hline $\begin{array}{l}\text { Low-Intensity } \\
\text { Distance }\end{array}$ & $\begin{array}{c}5269.8 \\
(4759.9,5779.8)\end{array}$ & $\begin{array}{c}5123.3 \\
(4986.4,5260.3)\end{array}$ & $\begin{array}{c}4964.3 \\
(4737.9,5910.6)\end{array}$ & $\begin{array}{c}5158.4 \\
(5057.2,5259.6)\end{array}$ & $\begin{array}{c}5164.6 \\
(5054.2,5275.1)\end{array}$ & $\begin{array}{c}5248.4^{c} \\
(5144.2,5352.6)\end{array}$ \\
\hline $\begin{array}{l}\text { Medium-Intensity } \\
\text { Distance }\end{array}$ & $\begin{array}{c}799.0 \\
(680.0,918.1)\end{array}$ & $\begin{array}{c}813.1 \\
(781.0,845.1)\end{array}$ & $\begin{array}{c}796.4 \\
(743.8,849.0)\end{array}$ & $\begin{array}{c}822.1 \\
(798.5,845.7)\end{array}$ & $\begin{array}{c}837.5 \\
(811.8,863.2)\end{array}$ & $\begin{array}{c}824.0 \\
(799.8,848.2)\end{array}$ \\
\hline $\begin{array}{l}\text { High-Intensity } \\
\text { Distance }\end{array}$ & $\begin{array}{c}350.6 \\
(277.1,424.1)\end{array}$ & $\begin{array}{c}358.7 \\
(338.9,378.6)\end{array}$ & $\begin{array}{c}340.3 \\
(307.5,373.1)\end{array}$ & $\begin{array}{c}367.1 \\
(352.5,381.8)\end{array}$ & $\begin{array}{c}373.3 \\
(357.4,389.2)\end{array}$ & $\begin{array}{c}360.2 \\
(345.2,375.2)\end{array}$ \\
\hline $\begin{array}{l}\text { Sprinting } \\
\text { Distance }\end{array}$ & $\begin{array}{c}77.3 \\
(51.7,102.9)\end{array}$ & $\begin{array}{c}72.9 \\
(66.0,79.8)\end{array}$ & $\begin{array}{c}62.5 \\
(51.1,73.8)\end{array}$ & $\begin{array}{c}76.0^{\mathrm{c}} \\
(70.9,81.1)\end{array}$ & $\begin{array}{c}74.9 \\
(69.3,80.4)\end{array}$ & $\begin{array}{c}76.6^{\mathrm{c}} \\
(71.3,81.8)\end{array}$ \\
\hline Player Load & $\begin{array}{c}816.1 \\
(750.2,882.0)\end{array}$ & $\begin{array}{c}796.3 \\
(778.9,813.7)\end{array}$ & $\begin{array}{c}774.9 \\
(746.1,803.6)\end{array}$ & $\begin{array}{c}799.8 \\
(786.9,812.6)\end{array}$ & $\begin{array}{c}803.5 \\
(789.4,817.5)\end{array}$ & $\begin{array}{c}799.4 \\
(786.2,812.6)\end{array}$ \\
\hline $\begin{array}{l}\text { Low-Intensity } \\
\text { Accel. Distance }\end{array}$ & $\begin{array}{c}3039.9 \\
(2733.8,3346.0)\end{array}$ & $\begin{array}{c}2964.2 \\
(2882.3,3046.1)\end{array}$ & $\begin{array}{c}2865.8 \\
(2730.4,3001.3)\end{array}$ & $\begin{array}{c}2981.9 \\
(2921.3,3042.4)\end{array}$ & $\begin{array}{c}2993.4 \\
(2927.3,3059.4)\end{array}$ & $\begin{array}{c}2967.5 \\
(2905.3,3029.7\end{array}$ \\
\hline $\begin{array}{l}\text { Medium-Intensity } \\
\text { Accel. Distance }\end{array}$ & $\begin{array}{c}189.6 \\
(168.1,211.2)\end{array}$ & $\begin{array}{c}188.6 \\
(182.8,194.3)\end{array}$ & $\begin{array}{c}184.4 \\
(174.9,193.9)\end{array}$ & $\begin{array}{c}189.8 \\
(185.5,194.1)\end{array}$ & $\begin{array}{c}193.0 \\
(188.3,197.6)\end{array}$ & $\begin{array}{c}190.2 \\
(185.8,194.6)\end{array}$ \\
\hline $\begin{array}{l}\text { High-Intensity } \\
\text { Accel. Distance }\end{array}$ & $\begin{array}{c}104.6 \\
(92.5,116.6)\end{array}$ & $\begin{array}{c}104.5 \\
(101.3,107.8)\end{array}$ & $\begin{array}{c}101.4 \\
(96.0,106.8)\end{array}$ & $\begin{array}{c}105.8 \\
(103.4,108.2)\end{array}$ & $\begin{array}{c}106.5 \\
(103.9,109.1)\end{array}$ & $\begin{array}{c}105.9 \\
(103.4,108.4)\end{array}$ \\
\hline $\begin{array}{l}\text { Max-Intensity } \\
\text { Accel. Distance }\end{array}$ & $\begin{array}{c}184.1 \\
(164.4,203.9)\end{array}$ & $\begin{array}{c}184.3 \\
(179.0,189.6)\end{array}$ & $\begin{array}{c}179.0 \\
(170.3,187.8)\end{array}$ & $\begin{array}{c}186.6 \\
(182.7,190.5)\end{array}$ & $\begin{array}{c}187.9 \\
(183.6,192.2)\end{array}$ & $\begin{array}{c}185.4 \\
(181.3,189.4)\end{array}$ \\
\hline $\begin{array}{l}\text { Low-Intensity } \\
\text { Decel. Distance }\end{array}$ & $\begin{array}{c}2261.0 \\
(2050.4,2471.5)\end{array}$ & $\begin{array}{c}2263.9 \\
(2207.4,2320.4)\end{array}$ & $\begin{array}{c}2208.0 \\
(2114.7,2301.3)\end{array}$ & $\begin{array}{c}2277.9 \\
(2236.2,2319.6)\end{array}$ & $\begin{array}{c}2287.9 \\
(2242.3,2333.4)\end{array}$ & $\begin{array}{c}2271.2 \\
(2228.4,2314.1)\end{array}$ \\
\hline $\begin{array}{l}\text { Medium-Intensity } \\
\text { Decel. Distance }\end{array}$ & $\begin{array}{c}165.1 \\
(144.8,185,4)\end{array}$ & $\begin{array}{c}167.3 \\
(161.8,172.8)\end{array}$ & $\begin{array}{c}164.8 \\
(155.8,173.8)\end{array}$ & $\begin{array}{c}170.2 \\
(166.1,174.2)\end{array}$ & $\begin{array}{c}172.9 \\
(168.5,177.3)\end{array}$ & $\begin{array}{c}169.3 \\
(165.2,173.5)\end{array}$ \\
\hline $\begin{array}{l}\text { High-Intensity } \\
\text { Decel. Distance }\end{array}$ & $\begin{array}{c}62.5 \\
(53.2,71.8)\end{array}$ & $\begin{array}{c}62.8 \\
(60.3,65.3)\end{array}$ & $\begin{array}{c}60.7 \\
(56.6,64.8)\end{array}$ & $\begin{array}{c}64.5 \\
(62.7,66.4)\end{array}$ & $\begin{array}{c}65.6^{c} \\
(63.6,67.6)\end{array}$ & $\begin{array}{c}63.2 \\
(61.3,65.1)\end{array}$ \\
\hline $\begin{array}{l}\text { Max-Intensity } \\
\text { Decel. Distance }\end{array}$ & $\begin{array}{c}48.1 \\
(39.1,57.1)\end{array}$ & $\begin{array}{c}46.9 \\
(44.5,49.4)\end{array}$ & $\begin{array}{c}43.4 \\
(39.4,47.4)\end{array}$ & $\begin{array}{c}47.4 \\
(45.6,49.2)\end{array}$ & $\begin{array}{c}48.4^{c} \\
(46.5,50.4)\end{array}$ & $\begin{array}{c}47.1 \\
(45.3,48.9)\end{array}$ \\
\hline
\end{tabular}


Figure 1. Perceived Wellness Questionnaire

\begin{tabular}{|c|c|c|c|c|c|}
\hline Category & 5 & 4 & 3 & 2 & 1 \\
\hline Fatigue & Very Fresh & Fresh & Normal & More Tired Than & Always Tired \\
\hline Sleep Quality & Very Restful & Good & & Restless Sleep & Cannot Sleep \\
\hline General Soreness & Feeling Great & Feeling Good & lormal & $\begin{array}{c}\text { Increase in Soreness } \\
\text { / Tightness }\end{array}$ & Very Sore \\
\hline Stress Levels & Very Relaxed & Relaxed & Normal & Feeling Stressed & Very Stressed \\
\hline Mood & Very Positive Mood & $\begin{array}{l}\text { Generally Good } \\
\text { Mood }\end{array}$ & $\begin{array}{c}\text { Less Interested in } \\
\text { Others / Activities } \\
\text { than Normal }\end{array}$ & $\begin{array}{l}\text { Aggravated / Short } \\
\text { Tempered }\end{array}$ & $\begin{array}{l}\text { Very Annoyed / } \\
\text { Irritable }\end{array}$ \\
\hline $\begin{array}{l}\text { How Many Hours } \\
\text { Did You Sleep? } \\
\text { (Sleep Quantity) }\end{array}$ & More Than 10 Hrs. & 8-10 Hrs. & 6-8 Hrs. & 4-6 Hrs. & Less than $4 \mathrm{Hrs}$. \\
\hline
\end{tabular}

